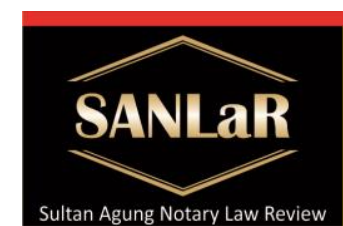

\title{
The Power of Proofing Use of Surrogate at The End of The Notary Deal
}

\section{Mucharoroh*)}

*) Students of Master of Notary Law, Faculty of Law, Universitas Islam Sultan Agung (UNISSULA) Semarang, Email: mucharoroh76@gmail.com

\begin{abstract}
The objectives of this study are to: 1) To determine and analyze the legal strength of the Surrogate at the end of the Notary Deed. 2) To find out and analyze the evidence if there is denial of the Surrogate at the End of the Notary Deed. The approach method in this research is a statute approach, a conceptual approach and a case approach. The research specification used is descriptive analytical, which is to describe the results of the study with data that is as complete and detailed as possible. The data required includes primary data, secondary data and tertiary data that can support the assessment, which is then analyzed using descriptive analysis methods. Based on the results of data analysis, it is concluded that: 1) The power of the Surrogate Law at the end of the Notary Deed has perfect legal power, because based on UUJN, the formal requirements of the Authentic Deed are signatures from the tappers and also the attachment of letters and documents and fingerprints of the tappers on the Minuta Akta Notary is proof of the authenticity of a Deed that has perfect legal force, likewise Surrogate is a substitute for signatures and fingerprints which have the same power as the signature. 2) Evidence that if there is denial of the Surrogate at the end of the Notary Deed, the Notary can deny it by showing that the Deed is in accordance with the procedures and provisions ordered by law, by presenting the witnesses who signed the Deed accompanied by a sheet showing the use of the Surrogate accompanied by an attachment to the Doctor's statement which was stated at the End of the Notary Deed. As for the form of Notary caution in using Surrogate in the Notary Deed so as not to experience denial in the future. Notaries perform all obligations ordered by law. And in the event that there is a denial of the truth of the Surrogate by one of the parties who feels that his/her rights have been harmed which aims to invalidate the Deed, it must be based on a Court Decision which begins with a lawsuit and the responsibility of proving an Authentic Deed on the party arguing or who filed a lawsuit.
\end{abstract}

Keywords: Power of Evidence; Surrogate; Notary Deed.

\section{Introduction}

One form of legal certainty itself is the existence of legal and written Evidence that has legal power, which basically is a public need as an effort to seek legal protection for actions. ${ }^{1}$

\footnotetext{
${ }^{1}$ Adinugraha, Calvin Oktafiano. (2015). "Kajian Kritis Hak Ingkar Notaris ".Solo: Jurnal Ilmiah Privat Law. p. 2
} 
The definition of a notary in the Civil Law System as regulated in Article 1 Ord, stbl. 1860 number 3 concerning the Position of Notary in Indonesia came into effect on July 1, 1860 which was later translated by Soegondo Notodisoedo (1993) which states that the meaning of a notary is as follows: "Notary is a General Officer, in particular (the only one) who is authorized to make Authentic Deeds regarding all actions, agreements, and decisions which are required by the General Legislation to be desired by those concerned that it is stated in a letter. Authentic, guarantees the date, keeps the Deeds and issues the grosse, copies (derivatives) and quotations thereof, all when making the Deed.

Signatures on an Authentic Deed actually have two basic legal functions, namely: ${ }^{3}$

1. Signing Identity Signs; and

2. As a sign of approval from the signing of the obligations attached to the Deed.

If the parties explain that they are unable to put their signature on the Deed or are unable to do so, then the information as well as the reasons for the obstruction must be clearly notified by the Notary in the Deed. An authentic deed or below is not considered a deed if it is not signed. In the Notary LawJN, it is mandatory that if the applicant is unable to sign due to paralysis, serious illness or other reasons then as a substitute for the signature, the applicant can put fingerprints on the Minuta Deed.

To overcome this problem, the Law provides a solution, namely by using Surrogate. Surrogate is a statement written by a notary based on direct information from the informer stating that the interlocutor is unable to put a signature and fingerprint due to certain reasons. ${ }^{4}$

It does not rule out the possibility that the Surrogate written by the Notary at the End of the Deed regarding the direct information from the suspect who is unable to sign and fingerprints turns out to be disputed by his heirs at a later date, causing problems in society that require legal certainty and also the need for legal protection for the Notary in carrying out his profession as Deed Maker Officer.

\section{Research Methods}

The approach method used in this study is primarily a descriptive analysis approach. Descriptive analysis is research that describes an analysis of existing findings. ${ }^{5}$ The analytical descriptive approach in this study is an approach in terms of Legislation and Legal Norms in accordance with existing problems.

\footnotetext{
2 Ngadino. (2019). Tugas dan Tanggung Jawab Jabatan Notaris di Indonesia. Cetakan Pertama. Semarang. Universitas PGRI Press. P. 3.

${ }^{3}$ wahyu utomo, Hatta Isnaini. (2016). Penggunaan Surrogate sebagai ganti Tanda Tangan dalam Akta Notaris dan Implikasinya terhadap kedudukan Akta. Jurnal Hukum, Universitas Narotama Surabaya. P. 3. ${ }^{4}$ www.translate.google.com, accessed March 15, 2020, based on the Dutch-Indonesian Dictionary, there are two, namely surrogate and surrogat which means substitute. In this study the authors chose to use the word surrogate which means a substitute for signature and fingerprint.

${ }^{5}$ Soekanto, and Soleman B. Taneko. (2001). Hukum adat Indonesia. Jakarta: Raja Grafindo Persada. p. 51.
} 


\section{Results and Discussion}

\subsection{Surrogate Legal Power at the End of Notary Deed}

Authentic Deed is perfect Evidence as stipulated in Article 1870 of the Civil Code, it provides among the parties, including their heirs or the person who gets rights from the parties, a perfect proof of what is done/stated in this Deed. , this means that it has such Evidence Strength because it is considered attached to the Deed itself so that it does not need to be proven again and for the Judge it is "Mandatory Evidence" (Verplicht Bewijs). Thus, whoever states that the Authentic Deed is fake then he must prove the Falsity of the Deed, therefore the Authentic Deed has the power of proof both physically, formally and materially. ${ }^{6}$

Still according to GHS Lumban Tobing. ${ }^{7}$ The things where the signature can be replaced by "Surrogaat", according to the Law are:

1. Cannot sign because of (illiteracy); and

2. Unable to sign, even if there is learning to write, which includes all things, where a person due to a situation, whether permanent or temporary, cannot put his signature under the Deed, even if he has writing skills.

So the interviewer who could not sign it (because he was not good at writing) or because he was unable to write, gave a statement: "I want to sign it, but I do not write and therefore I am not good at writing and therefore I cannot sign my signature."

Or explain:

"I was unable to sign my signature, because .....".

GHS Lumban Tobing argue that 8 "Matters where the signature can be replaced by the so-called" Surrogate "according to the Law are:

(1) in the case of being unable to sign his/her because the person concerned is illiterate, and

(2) in the event of being unable to sign his/her signature, even if the person concerned is not illiterate, which includes all matters, or circumstances, where a person due to a situation, whether permanent or temporary, cannot sign under the Akad. that, even though he has the will to write.

There are 2 (two) possibilities that the applicant cannot sign: ${ }^{9}$

a. The audience can read and write, physically cannot sign because his hand hurts (eg stroke, tremor, Parkinson's) or does not have fingers or does not have hands. If this happens use Surrogate.

When an applicant is unable to sign his/her signature, the substitute for that signature is called a Surrogate, whose power is the same as the signature, namely a statement from the informer (not a notary's statement) written by a notary, that he is unable to

\footnotetext{
${ }^{6}$ Tjukup, I Ketut, I Wayan Bela Siki Layang, Nyoman A. Martana, I Ketut Markeling, Nyoman Satyayudha Dananjaya, I Putu Rasmadi ArshaPutra, Komang Widiana Purnawan, Made Diah Sekar Mayang Sari, Ketut Nihan Pundari and Putu Ayu Ratih Tribuana, 2015-2016 , Akta Notaris (Akta Autentik) sebagai Alat Bukti dalam Peristiwa Hukum Perdata, Scientific Journal of Notary Masters Study Program, page 182.

${ }^{7}$ Ibid.

${ }^{8}$ Thong Kie, Tan. (2007). Stusi Notariat dan serba-serbi Praktek Notaris. Jakarta: Ichtiar Baru Van Hoeve. p. 480 .

${ }_{9}$ Adjie, Habib and Rusdianto Sesung. (2020). Tafsir, Penjelasan, dan Komentar atas Undang-undang Jabatan notaris. Bandung: Refika Aditama. p. 448.
} 
sign for certain reasons stated expressly in the Deed, In this case used Surrogate. This can be called "Description prevented from writing". This kind of provision can be applied in Article 44 point 1 and 2 UUJN-P.

b. The tappers physically have complete hands and fingers, but cannot read and write, if this happens, they must put their fingerprints on the sheet provided for that purpose. (Article 16 number (1) letter c UUJN-P). In this case, the affixing of a certain fingerprint is the same as the signature. This may be called "Unwritten description".

c. Article 16 number (1) letter c UUJN-P provides space for an applicant who is unable to sign his/her signature and as evidence he comes before the Notary and agrees with the Deed made before the Notary by affixing his fingerprint on the sheet provided for the purpose the. And it can be considered as not facing and not agreeing if there is no fingerprint, which will make it difficult for the notary if there is a denial by the notary. In response to understanding the rules for using/applying fingerprints mentioned above, become a Notary Decision Maker after diving and understanding the substance of the provisions mentioned above. ${ }^{10}$

According to Setyawati, ${ }^{11}$ The definition of tappers is a person who needs Notary Services or PPAT, then that person must come to the Notary Office or PPAT. If this cannot be done by the person concerned, they may not appear at the Notary Office or PPAT, but this can be done face to face (Notary or PPAT comes to the place of the person who needs the service, if it meets 3 (three) criteria, namely:

1. Because the person concerned is seriously ill;

2. Assisted Residents (Prisoners); and

3. Because old or already rented.

According to UUJN, the formal requirements of the Authentic Deed are signatures of the parties. And the attachment of letters as well as documents and fingerprints of the tappers on the Minuta Deed of Notary is proof of the authenticity of a Deed that has perfect legal power, likewise Surrogate is a substitute for signatures and fingerprints with the same strength as the signature. Thus the Law of Surrogate has perfect Law of Proof of Strength.

3.2 Proof of denial of the Surrogate at the End of the Notary Deed

In order to avoid denial by the parties of the Notary Deed, the Notary shall conduct business in the form of:

a. Read out the contents of the Notary Deed;

b. Carry out all Notary Obligations; and

c. Attaching letters and documents and fingerprints of the tapes to the Minuta Deed.

In Notary Practices, sometimes Notaries face where this is not clearly explained in the Regulation, because of this, Notaries are required to be problem solvers and solutions to problems faced by the community and also able to accommodate the interests of the community, making Notaries explore by exploring the applicable Positive Laws and Regulations. to find answers and solutions to a problem. This also applies when an applicant who is unable to put a signature and fingerprint due to certain reasons, by utilizing the facilities provided by the Law in the form of using Surrogate makes it easy for Notaries to carry out their duties for the benefit of their Service Users.

\footnotetext{
${ }^{10}$ Adjie, Habib and Rusdianto sesung. Op Cit. p. 453.

${ }^{11}$ Setyawati. (2020). Cyber Notary. Unissula. p. 448.
} 
So a Surrogate that is made by formulating the right sentence can also prevent a later denial. Denial of a Notary Deed is not impossible, to prevent this kind of thing (denial) can be done by applying the provisions that have been regulated by UUJN, namely those contained in Article 16 paragraph (1) letter $m$ which states "read out the Deed in front of the audience with attended by at least 2 (two) witnesses or 4 (four) special witnesses for the maker of an Underhanded will and signed on the spot by the parties, witnesses and notaries".

As a form of prudence, the Notary makes every effort to prevent future denial of the Surrogate by carrying out all obligations ordered by law, but if this happens then the Notary can deny it by presenting witnesses who signed the Deed accompanied by a sheet showing the use of the Surrogate, accompanied by a doctor's certificate attached at the end of the Notary Deed.

Based on Article 1866 BW, one of the Evidence Tools, namely written Evidence and Authentic Deed is a form of written evidence. The legal basis for this proof is Article 1865 BW: "Every person who argues that he has something right or to confirm his own right or deny a right or to confirm his own right or deny a right or to confirm his own right or deny someone else's right, then that person must prove the existence of the right or the event ".

Based on the Article above, it means that every person who acknowledges having rights and mentions an event or denies the existence of the right or event is an obligation for him to prove before the court, in the event that there is a denial of the truth of the Surrogate by one of the parties who feels his right has been impaired which aims to make The deed becomes invalid, it must be based on a court decision which begins with a lawsuit and the responsibility of proof of an authentic deed on the party arguing or submitting the lawsuit.

\section{Closing}

\subsection{Conclusion}

1. The Legal Power of the Surrogate at the End of the Notary Deed has the perfect legal power of proof, because based on UUJN, the formal requirements of the Authentic Deed are the signatures of the parties and the attachment of Letters and Documents and the fingerprints of the tappers on the Minuta Deed of Notary are proof of the authenticity of a Deed that has Power of Law is perfect, so Surrogate is a substitute for signature and fingerprint which has the same power as signature.

2. Evidence if there is denial of the Surrogate at the end of the Notary Deed, the Notary can deny it by showing the Deed he has made in accordance with the procedures and provisions ordered by law, by presenting witnesses who signed the Deed accompanied by a sheet showing the use of the Surrogate which is also completed Attachment of Doctor's certificate which states at the End of the Notary Deed. As for the notary's caution in using the Surrogate in the Notary Deed so as not to be denied in the future, the Notary carries out all the obligations 
ordered by law. And in the event that there is a denial of the truth of the Surrogate by one of the parties who feels that his right is harmed which aims to make the invalid Deed.

\subsection{Suggestion}

1. The need for a written rule that clearly states the use of Surrogate or fingerprints for applicants who are unable to sign a Partij Deed so that Legal Certainty can be achieved and become a guideline for Notaries in carrying out their duties; and

2. Notary in carrying out his/her position duties always acts carefully, is careful and learns to increase his/her knowledge in order to learn more about the applicable laws and regulations in order to minimize the possibility of an act or deed that is disputed and denied by the parties concerned.

\section{References}

Journals:

[1] Wahyu Utomo, Hatta Isnaini. (2016). Penggunaan Surrogate sebagai ganti Tanda Tangan dalam Akta Notaris dan Implikasinya terhadap kedudukan Akta. Jurnal Hukum, Universitas Narotama Surabaya.

[2] Tjukup, I Ketut, I Wayan Bela Siki Layang, Nyoman A. Martana, I Ketut Markeling, Nyoman Satyayudha Dananjaya, I Putu Rasmadi ArshaPutra, Komang Widiana Purnawan, Made Diah Sekar Mayang Sari, Ketut Nihan Pundari and Putu Ayu Ratih Tribuana, 2015-2016 , Akta Notaris (Akta Autentik) sebagai Alat Bukti dalam Peristiwa Hukum Perdata, Scientific Journal of Notary Masters Study Program.

Books:

[1] Adinugraha, Calvin Oktafiano. (2015). "Kajian Kritis Hak Ingkar Notaris ".Solo: Jurnal Ilmiah Privat Law.

[2] Adjie, Habib and Rusdianto Sesung. (2020). Tafsir, Penjelasan, dan Komentar atas Undang-undang Jabatan notaris. Bandung: Refika Aditama

[3] Ngadino. (2019). Tugas dan Tanggung Jawab Jabatan Notaris di Indonesia. Cetakan Pertama. Semarang: Universitas PGRI Press.

[4] Setyawati. (2020). Cyber Notary. Unissula.

[5] Soekanto, and Soleman B. Taneko. (2001). Hukum adat Indonesia. Jakarta: Raja Grafindo Persada

[6] Thong Kie, Tan. (2007). Stusi Notariat dan serba-serbi Praktek Notaris. Jakarta: Ichtiar Baru Van Hoeve. 
Internet:

www.translate.google.com, accessed March 15, 2020, based on the Dutch-Indonesian Dictionary 